\title{
Design considerations for massively parallel sequencing studies of common familial cancers
}

\author{
BJ Feng ${ }^{1}$, SV Tavtigian², MC Southey ${ }^{3}$, DE Goldgar ${ }^{1 *}$ \\ From Familial Aspects of Cancer 2011 Research and Practice: A combined meeting of kConFab, Australian \\ Breast Cancer Family Study, Australian Colorectal Cancer Family Study, Australian Ovarian Cancer Study, \\ Family Cancer Clinics of Australia and New Zealand and kConFab \\ Kingscliff, Australia. 23-26 August 2011
}

Massively Parallel Sequencing (MPS) allows sequencing of entire exomes and genomes to now be done at reasonable cost, and its utility for identifying genes responsible for rare Mendelian disorders has been demonstrated. However, for a complex disease such as the common cancers, study designs need to accommodate substantial degrees of locus, allelic, and phenotypic heterogeneity, as well as complex relationships between genotype and phenotype. Such considerations include careful selection of samples for sequencing and a welldeveloped strategy for identifying the few "true" disease susceptibility genes from among the many irrelevant genes that will be found to harbor rare variants. To examine these issues we have performed simulationbased analyses in order to compare several strategies for MPS sequencing in complex disease. Factors examined include genetic architecture, sample size, number and relationship of individuals selected for sequencing, and a variety of filters based on variant type, multiple observations of genes and concordance of genetic variants within pedigrees. A two-stage design was assumed where genes from the MPS analysis of high-risk families are evaluated in a secondary screening phase of a larger set of probands with more modest family histories. Designs were evaluated using a cost function that assumed the cost of sequencing the whole exome was 400 times that of sequencing a single candidate gene. Results indicate that while requiring variants to be identified in multiple pedigrees and/or in multiple individuals in the same pedigree are effective strategies for reducing false positives, there is a danger of over-filtering so that most true susceptibility genes are missed. In

Department of Dermatology, University of Utah School of Medicine, Salt Lake City, UT, USA

Full list of author information is available at the end of the article most cases, sequencing more than two individuals per pedigree results in reduced power without any benefit in terms of reduced overall cost. Further, our results suggest that although no single strategy is optimal, simulations can provide important guidelines for study design. Examples in familial breast cancer and melanoma will be presented to illustrate these points.

\section{Author details}

'Department of Dermatology, University of Utah School of Medicine, Salt Lake City, UT, USA. ${ }^{2}$ Huntsman Cancer Institute and Department of Oncological Sciences, University of Utah, Salt Lake City, UT, USA.

${ }^{3}$ Department of Pathology, University of Melbourne, VIC 3010, Australia.

Published: 12 April 2012

doi:10.1186/1897-4287-10-S2-A38

Cite this article as: Feng et al:: Design considerations for massively parallel sequencing studies of common familial cancers. Hereditary Cancer in Clinical Practice 2012 10(Suppl 2):A38.

Submit your next manuscript to BioMed Central and take full advantage of:

- Convenient online submission

- Thorough peer review

- No space constraints or color figure charges

- Immediate publication on acceptance

- Inclusion in PubMed, CAS, Scopus and Google Scholar

- Research which is freely available for redistribution

\section{Biomed Central}

